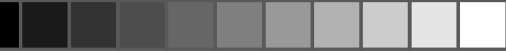

\title{
INVESTIGATING TECHNICAL INSTRUCTORS PERCEPTIONS OF SAFETY CULTURE USING PARTIAL LEAST SQUARE-STRUCTURAL EQUATION MODELLING (PLS-SEM) IN MALAYSIAN EDUCATION SECTOR
}

\author{
NOR KAMILAH MAKHTAR* \\ BALAKRISHNAN PARASURAMAN,PHD** \\ MOHD NAZRI ZAKARIA,PHD*** \\ AHMAD RASDAN ISMAIL,PHD**** \\ nkamilahm@gmail.com
}

\begin{abstract}
Abstrak
Keselamatan merupakan isu pekerjaan yang penting untuk ditangani kerana implikasinya kepada organisasi. Kajian budaya keselamatan semakin meningkat di kebanyakan sektor pekerjaan. Bagaimanapun, kurang tumpuan kajian budaya keselamatan di sektor pendidikan terutamanya di Malaysia. Kajian ini dijalankan untuk menguji faktor-faktor yang mempengaruhi budaya keselamatan di sektor pendidikan sebagai penambahan sorotan literatur dalam kajian budaya keselamatan di tempat kerja. Satu tinjauan telah dijalankan di Kolej Vokasional (KV) seluruh Malaysia, yang merupakan salah satu institusi pendidikan teknik dan vokasional di Malaysia, melibatkan 380 pengajar dalam kursus teknologi kejuruteraan di KV. Analisis menggunakan perisian SmartPLS digunakan untuk menguji hipotesis kajian. Model pengukuran telah mengesahkan kebolehpercayaan dan kesahan lima faktor budaya keselamatan yang dikaji. Analisis model berstruktur mendapati pengetahuan keselamatan merupakan pemboleh ubah peramal budaya keselamatan yang paling penting, diikuti oleh peraturan keselamatan, latihan keselamatan dan komunikasi keselamatan. Walau bagaimanapun, tiada hubungan yang signifikan didapati antara komitmen pengurusan dan budaya keselamatan di kalangan pengajar KV. Penguatkuasaan pematuhan Akta Keselamatan dan Kesihatan Pekerjaan 1994 di semua organisasi dalam sektor pendidikan oleh Kementerian Pendidikan Malaysia dilihat sebagai satu langkah yang perlu untuk mencapai budaya keselamatan yang positif dalam sektor pendidikan. Kempen, bengkel dan latihan juga perlu dijalankan oleh kerajaan bagi meningkatkan kesedaran tenaga pengajar/guru berkaitan budaya kerja yang selamat. Pihak pengurusan dan tenaga pengajar/guru perlu memainkan peranan dan tanggungjawab masing-masing untuk memastikan objektif budaya keselamatan dapat dicapai.
\end{abstract}

Kata Kunci: Budaya Keselamatan, Pendidikan, PLS-SEM, Tenaga Pengajar Kolej Vokasional

* Pensyarah di Institut Pendidikan Guru Kampus Kota Bharu, Kelantan, Malaysia

** Profesor di Fakulti Keusahawanan dan Perniagaan, Universiti Malaysia Kelantan, Malaysia

*** Pensyarah kanan di Fakulti Keusahawanan dan Perniagaan, Universiti Malaysia Kelantan, Malaysia

**** Profesor Madya di Fakulti Teknologi Kreatif dan Warisan, Universiti Malaysia Kelantan, Malaysia 


\begin{abstract}
Safety is an important employment issue that needs to be tackled because of the implications it brings to organizations. Studies on safety culture have been increasing recently in many occupational sectors. However, less focus has been given to safety culture studies in the education sector particularly in Malaysia. Adding to the safety culture research literature, this study examined to what extent factors that affect the safety culture at education sector. A survey was conducted in Vocational Colleges (VC) all over Malaysia, as one of technical and vocational institution in Malaysian Education sector, involve 380 instructors teaching in engineering technology courses at VC. Partial least square (PLS) analysis was employed in this study to test the research hypothesis. The measurement model resulted in five factors of safety culture which validity and reliability were confirmed. The analysis on the structural model revealed that safety knowledge is the most significant predictor of safety culture, followed by, safety regulations, safety training and safety communication. However, no significant effect was found for management commitment towards safety culture among the instructors. Furthermore, in order to achieve a positive safety culture in education sector, the Ministry of Education needs to enforce a compliance of Occupational Safety and Health Act 1994 at all organizations in education sector. Beside that, campaigns, workshops and also trainings need to be carried out by the government in order to increase instructors/teachers awareness of safe work culture. Both the management and instructors/teachers need to play their own roles and responsibility in order to ensure the objective of safety culture is achieved.
\end{abstract}

Keywords: Safety Culture, Education, PLS-SEM, Technical Instructors

* $\quad$ Lecturer at Teacher Training Institute Kota Bharu Campus, Kelantan, Malaysia

** Professor at Faculty of Bussiness and Enterpreneurship, Universiti Malaysia Kelantan, Malaysia

*** Senior Lecturer at Faculty of Bussiness and Enterpreneurship, Universiti Malaysia Kelantan, Malaysia

*** Associate Professor at Faculty of Creative Technology and Heritage, Universiti Malaysia Kelantan, Malaysia 

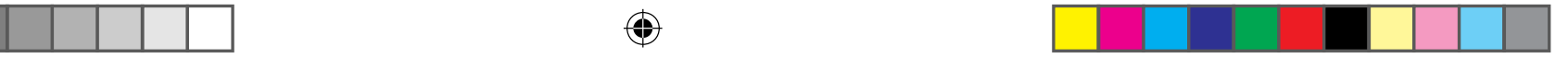

\subsection{Introduction}

Safety can be defined as liberation from risk, injury and danger (Kumar, Chelliah, Chelliah, \& Amin, 2012). In addition, safety can also be the manifestation of "caution" in order to avoid danger. While culture is defined as the values and beliefs that are being shared in order to create an identity of a group of people (Guldenmuld, 2010). Therefore, safe work culture can be defined as the patterns of behaviours and attitudes or products of people, which creates commitment and efficiency in an organization (Hale, 2000).

Statistic of occupational accident reported in Malaysia illustrated an increasing number of accidents in Public Services and Statutory Bodies during 2012-2016 and decrease slowly at 2017 (reported until October) (DOSH, 2018). There is an increasing number of accident happen in this sector which is from $0.96 \%$ in 2015 and incresed to $3 \%$ in 2016 and slowly decreased at $1.45 \%$ until last October of 2017. Based on the press reports, there were 47 cases of accidents involving injuries and even deaths occurred in school area (Makhtar, Parasuraman, Zakaria, \& Ismail, 2018).The accidents and their consequences continue to be a major public health concern even though the statistic data on accidents occurred in this sector are lower than other sectors such as manufacturing, construction and others. Newspaper keeps reporting on many accident cases occurred in education sector showing some indicator of low level of safety culture (Makhtar et al., 2018). This will make the school that at first plays the role as the place to gain knowledge becomes a place that does not have safety guarantee.

School safety in places such as vocational schools, technical training schools, apprenticeship training centers and job training centers is particularly important (Öner, Tanır, Aktaş, Okyay, \& Şaşmaz, 2017). Technical and vocational instructors primarily have responsible for imparting practical skills and knowledge in specific area to students by the use of tools, machine and materials in the workshop (Usman \& Rashid, 2014). A previous study concluded that vocational education pupils had a limited knowledge of how to prevent health risks at work and lacked a systematic way to approach hazard control (Öner et al., 2017). It is very important to protect students from possible risks and hazards and to ensure their safety in school or in places where educational activities are performed. Instructors at vocational school plays an important role in practising and delivering safety awareness and practices among students since this foundation may affect their working experiences for many years to come. Instructors must play a good role in showing a good safety culture at a workplace.

To ensure that a vocational college as one of technical based schools in Malaysia is a safe institution for the instructors to work at and for the students to gain knowledge and skills, a study must be conducted to identify how far the instructors demonstrate safety culture during their teaching and learning process in the workshop. In addition, the Ministry of Education and the school must constantly 

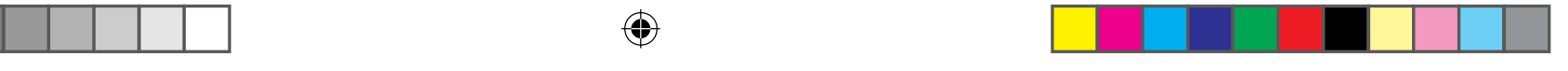

identify the safety weaknesses in the implementation of existing safety practices. Thus, in order to minimize the rate of accident at education sector as a workplace, enactment of the Occupational Safety and Health Act (OSHA) in 1994 which aimed at self-regulation and also to improve the safety and health of the employee (Ismail et al., 2012) need to be complied by education sector although the number of accidents rates in this sector are quite low rather than other sectors such as construction and manufacturing.

In this study, the main purpose was to identify factors that can influence safety culture of the technical instructors at Vocational College (VC). Specifically, the study focused on the investigation on examining whether safety communication, management commitment, safety rule, safety knowledge and safety training can contribute to technical instructors' safety culture. Thus, till now there was little measurement established to enable the profession to quantify and analyze safety culture in the Malaysian education sector. Safety behavior can be improved by establishing a safety culture, even safety per- formance and degree of safety.

\subsection{Theoretical Framework and Hypothesis Development}

\subsection{Theoretical Framework}

Bandura (1986) tried to interpret the concept of safety culture in terms of reciprocal determinism based on social cognitive theory, and derived three components: behaviour, person and environment. Geller (1997) adopted Bandura (1986) work and made an excellent effort to identify the characteristics for each component and that leading to the development of a model called Total Safety Culture. Choudhry, Fang, \& Mohamed (2007) also adopted and developed Bandura (1986), asserted through his new model that safety culture is a product based on interactions between people, jobs and organisations and called that model as a Reciprocal Safety Culture model. Safety Culture Table model developed by Ho and Zeta (2004) involved elements like person, environment, behaviour and organisation, and they pointed out that safety culture is similar to the table that is constructed on four legs.

In 2000, Cooper proposed the Reciprocal Safety Culture model by adopting the Bandura's model of Reciprocal Determinism, which was derived from Social Cognitive Theory (SCT). This model suggested that the concept of safety culture aimed to facilitate the measurement and quantification of safety culture. The Reciprocal Safety Culture model presents an integrative way of thinking about many processes that impact on safety culture, a set of measurement techniques that do not depend solely on incident or accident index and, a dynamic framework that can be used to perform a multilevel analysis of the safety culture (Sukadarin, Suhaimi, \& Abdull, 2012). It also emphasized that the safety culture can be measured by examining the reciprocal interaction between safety management systems; people perceptions about

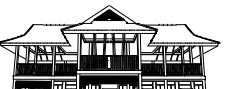


safety and people's actual safety related behavior (Cooper, 2002). Research at the construction sector in Malaysia by Ismail et al., (2012), adopted Cooper's model to develop a framework for operationalization of construction safety culture which involved three phases: psychological (value \& beliefs), behavioural and situational (observable practices \& provided environment) and safety officers \& supervisors (communication, trust $\&$ commitment).

Using Reciprocal Safety Culture Model by Cooper (2000) as a baseline, this study specifically looked into safety communication (behavioural), management commitment (behavioural), safety rule (situational), safety knowledge (psychological) and safety training (situational) as key contributors to safety culture among instructors at vocational college. The framework of this study is as illustrated in Figure 1.

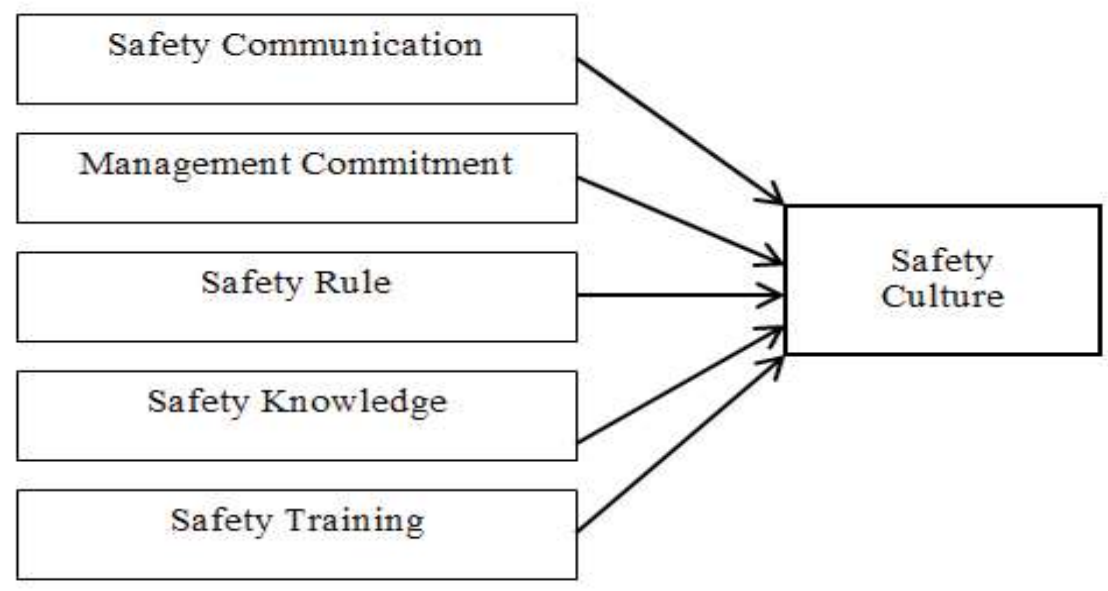

Figure 1: The theoretical framework of the study 

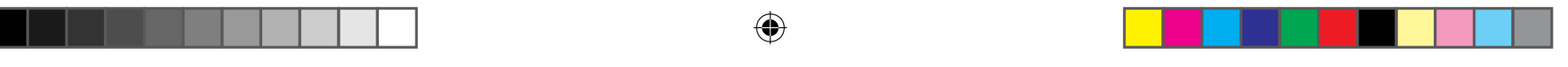

\subsection{Hypothesis Development}

Safety communication is defined as a process of exchanging information between two or more people with regards to safety related issues (Skeepers \& Mbohwa, 2015). Safety communication can be structured into two categories: formal and informal communication. Formal communication includes communication from upper management (superiors/supervisors), written formal communication, training and toolbox talk meanwhile informal communication is communication amongst employees which is sometimes referred to as ad-hoc communication (Alsamadani, 2013). In addition, Vecchio-sadus (2007) affirms that safety communication comes in various types, for example, incident reports, safety performance, workplace inductions, and procedures and policies. Upper management communication, also called as downward communication, is from upper to low level management. For instance, communication between manager to immediate supervisor and from supervisor to subordinates. This type of communication shows that subordinates receive information or instruction from their leader in order to do tasks or carry out daily work. Besides, most of studies focused on supervisor communication, which it revealed that subordinates are more close to their supervisor compared to the upper management. Therefore, there is still limited study that focuses on safety communication related to safety with employees' safety culture especially in Malaysian' education sector setting. Thus, confirming the need of more research on the topic. Therefore, it is hypothesised that:

\section{H1: Safety communication is positively related to safety culture}

Most literature is unanimous in identifying management commitment as a pre-requisite for safety, the general reason being that management is responsible for establishing objectives, developing strategies, allocating resources, development and implementing systems and by virtue of its role setting an example (Feng et al., 2011). Management plays a key role in promoting a positive safety culture. This can be best demonstrated by allocating resources, time, walk the talk, inspections, by participating in risk assessments and consultative committee meetings, and by completing actions (Choudhry et al., 2007). The ways in which the management commitment's reflected, according to Faridah et al. (2011); participation, visibility, supportive, demonstrate leadership, positive attitude towards safety, in control of the activities, and the existence of values, belief and the acknowledged significant safety programmes. Therefore, it is hypothesised that:

$\mathrm{H} 2$ : Management commitment is positively related to safety culture 


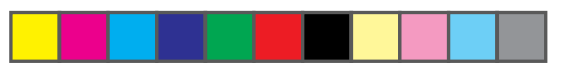

Safety rules, break of safety rules and attention to rules or procedures are among of the checklist of safety behaviour. Safety culture deals with the "unwritten rules" (clarified by action) that determine if safety really is important in an organization (Cram, 2015). On organization will suffers from poor safety and health conditions as safety rules do not exists and work hazards at the workplace are not perceived (Ibrahim, Hallaq, \& Enshassi, 2012). Workers' attitudes towards safety are influenced by their perception of risk, management, safety rules and procedures. Therefore, it is hypothesised that:

\section{H3: Safety rule is positively related to safety culture}

Most researchers suggested safety knowledge should be exposed as early as possible for developing safety culture (Koo, Nurulazam, Rohaida, Teo, \& Salleh, 2014). The concept of exposing safety at education level compared the beginning of working environment would lead to a better safety practices among young workers (Reinhold, Siirak, \& Tint, 2014). Researchers hypotheses that young adults may choose to ignore hazardous condition and situation in the academic laboratory may be due to lack of safety knowledge and safety training. Therefore, it is hypothesised that:

\section{H4: Safety knowledge is positively related to safety culture}

Training refers to instruction and practice for acquiring skills and knowledge of rules, concepts, or attitudes necessary to function effectively in specified task situations (Cohen \& Colligan, 1998). Safety training has been recognized as an important organizational characteristic distinguishing organization with successful safety program (Zohar, 1980), and is an effective means for employees to enhance their skills and knowledge of safety in the organizations (Shea et al., 2016).Based on literature, the aspects of training are not limited to but include the safety and health responsibilities of all personnel concerned, regularly and thoroughly in specific job techniques, new employees are given extensive safety training, immediately after hiring, the dedicated time allocated and its effectiveness (Ismail et al., 2012). Training activities should include short talks, group meetings, training for personal witness, hygiene, workplace stress and responsibilities towards safety (including compliance with rules and regulations, hazard identification and risk assessment, incident investigation and job safety analysis)(Choudhry et al., 2007). Therefore, it is hypothesised that:

H5: Safety training is positively related to safety culture 


\subsection{Research Methodology}

The research model developed in this research was tested using Partial Least Squares (PLS), a variance-based structural equation modelling approach (Jörg Henseler, Ringle, \& Sarstedt, 2014). PLS has the ability to facilitate the assessment of both the measurement and structural models (Roldán, Felipe, \& Leal-Rodríguez, 2015). This study used PLS analysis for two main objectives: firstly, the aim of the study was oriented towards prediction of the dependent variable (Vinzi et al.,, 2010), and secondly, the latent variables' scores were used in the subsequent analysis for predictive relevance (Hair et al., 2014). Hair et al. (2014) further stressed that these arguments have led to the widespread acceptance of PLS in much research. Specifically, this study used the SmartPLS approach introduced by Ringle, Wende, and Will (2005).

All of the constructs were measured based on scales developed by previous researchers. Safety knowledge, safety training and management commitment was measured based on a scale developed by Vinodkumar and Bhasi, (2010) with Cronbach's alpha reported was $0.77,0.82$ and 0.86 . Safety communication was measured based on a scale developed by Abdullah (2010). The Cronbach's alpha reported by Abdullah (2010) was 0.88 . Safety rule was measured based on a scale developed by Idrus et al., (2004) containing five items with the reported Cronbach's alpha was 0.92 . The items or measures for all these variables were anchored on a 5-point Likert scale ( $1=$ strongly disagree to $5=$ strongly agree).

Unit of analysis are the instructors working at Malaysia TVET sector specifically in Vocational College (VC). Those from Vocational College who involved in teaching Engineering and Technology courses. To decide on the sample size of the respondents for this study, we first used the GPower software to calculate the minimum sample size required. Since the model had a maximum of 5 predictors, the effect size was set as medium (0.15) and power needed as 0.95 . The sample size required was 138 . Hence we set out to collect data that was larger than the required number.

There were about 62 VCs all over Malaysia that offer Engineering Technology courses. 38 VCs were randomly selected using cluster-sampling technique (the type of probability sampling). A total of 447 sets of questionnaires were distributed and 397 questionnaires were returned with the response rate of $89 \%$. With 6 of the questionnaires were not fully answered and some were taken out due to outliers, 380 were accepted for further analysis based on cluster sampling technique. The data collected are analyzed and interpreted using both of the SPSS Version 24 software and the SmartPLS 3.0 software (Ringle, Wende, \& Will, 2005). 
Before using PLS-SEM for the analysis, data were also tested to check for common method variance. Common method variance is an issue when a single latent variable accounts for the majority of the explained variance (Podsakoff et al., 2003). To check for such bias, this study uses the method introduced by (Kock, 2015) which is by testing the common method bias through VIF value. According to Kock (2015), using PLS-SEM, a VIF value greater than 3.3 is recommended as an indicator of pathological collinearity, as well as an indication that the model may be contaminated by a generalized bias. Therefore, if all (the factors) of VIF generated from the full collinearity test are equal to or lower than 3.3, the model can be considered independent of the comman method bias. After full collinearity test for all the factors in this model, it is found that the internal VIF value for all the factors in this model is less than 3.3. Thus, it can be summarized that such bias due to the use of the same likert scale for all the factors studied was not a serious problem in the present study.

\subsection{Results and Analysis}

\subsection{Demographic Profile}

A total of 380 VC instructors responded to the questionnaire. The SPSS 24 software was used to obtain the frequencies of the demographic profile. The response rate of this research questionnaires feedback was $89 \%$ of sample size. In summary, the majorities of the respondents are more than 46 years old $(33.7 \%)$, are male $(68.7 \%)$, are equipped with undergraduate degrees $(69.5 \%)$ and with working experience more than 15 years in $\mathrm{VC}(45.0 \%)$. 


\subsection{Assessment of Measurement Model}

Based on partial least squares structural equation modeling (PLS-SEM), the measurement model was assessed first using SmartPLS 3.0. To assess the measurement model, the convergent validity, discriminant validity, and reliability of the measurements used were examined.

To assess convergent validity, the factor loadings and the average variance extracted (AVE) were examined. First of all, the factor loadings of each variable were inspected. The individual loadings that are above 0.70 on each variable are deemed significant (Hair et al., 2014). Indicators with very low loadings below 0.40 should be deleted (Hair et al., 2014). No indicators were below 0.40 and as a result, no indicators were deleted. There are several indicators that are between 0.40 and 0.70 but it was not required to be deleted because the AVEs are already above the recommended values (Hair et al., 2014). As shown in Table 1 below, all of the AVEs are above 0.50, which is the recommended cut-off value (Hair et al., 2014). The rest of the indicators have loadings well above 0.70 for each respective variable. Thus, the measurements used for each variable in this study are convergently valid.

To assess discriminant validity, the correlations between the measures were compared with the square root of the AVEs. As depicted in Table 2 below, all of the correlations between the measures are lower than the square root of the AVEs, which are bolded on the diagonals. Therefore, the measurements used for each variable in this study are discriminantly valid.

To assess reliability, the composite reliability for each variable was examined. As shown in Table 1 below, the composite reliability for all variables are above 0.60 , which is the acceptable cut-off value (Hair et al., 2014). Therefore, the measurements used for each variable in this study are reliable.

Table 1: Convergent Validity of Measurement Model

\begin{tabular}{|l|l|c|c|c|}
\hline $\begin{array}{c}\text { Model Con- } \\
\text { struct }\end{array}$ & \multicolumn{1}{|c|}{ Items } & Loadings & AVE & CR \\
\hline \multirow{2}{*}{$\begin{array}{l}\text { Safety Commu- } \\
\text { nication }\end{array}$} & COM1 & 0.907 & \multirow{2}{*}{0.814} & 0.946 \\
\cline { 2 - 3 } & COM2 & 0.926 & & \\
\cline { 2 - 3 } & COM3 & 0.880 & & \\
\cline { 2 - 3 } & COM4 & 0.896 & & \\
\hline
\end{tabular}




\begin{tabular}{|c|c|c|c|c|}
\hline \multirow{6}{*}{$\begin{array}{l}\text { Management } \\
\text { Commitment }\end{array}$} & MC1 & 0.745 & \multirow[t]{6}{*}{0.611} & \multirow[t]{6}{*}{0.904} \\
\hline & MC2 & 0.838 & & \\
\hline & MC3 & 0.848 & & \\
\hline & MC4 & 0.798 & & \\
\hline & MC6 & 0.747 & & \\
\hline & MC7 & 0.703 & & \\
\hline \multirow[t]{5}{*}{ Safety Rule } & RULE1 & 0.762 & \multirow[t]{5}{*}{0.614} & \multirow[t]{5}{*}{0.888} \\
\hline & RULE2 & 0,812 & & \\
\hline & RULE3 & 0.805 & & \\
\hline & RULE4 & 0.822 & & \\
\hline & RULE5 & 0.712 & & \\
\hline \multirow{6}{*}{$\begin{array}{l}\text { Safety Knowl- } \\
\text { edge }\end{array}$} & SKNOW1 & 0.747 & \multirow[t]{6}{*}{0.619} & \multirow[t]{6}{*}{0.907} \\
\hline & SKNOW2 & 0.797 & & \\
\hline & SKNOW3 & 0.805 & & \\
\hline & SKNOW4 & 0.797 & & \\
\hline & SKNOW5 & 0.806 & & \\
\hline & SKNOW6 & 0.789 & & \\
\hline \multirow[t]{6}{*}{ Safety Training } & TRAIN1 & 0.839 & \multirow[t]{6}{*}{0.663} & \multirow[t]{6}{*}{0.922} \\
\hline & TRAIN2 & 0.846 & & \\
\hline & TRAIN3 & 0.778 & & \\
\hline & TRAIN4 & 0.835 & & \\
\hline & TRAIN5 & 0.788 & & \\
\hline & TRAIN6 & 0.795 & & \\
\hline \multirow[t]{5}{*}{ Safety Culture } & SC1 & 0.781 & \multirow[t]{5}{*}{0.613} & \multirow[t]{5}{*}{0.888} \\
\hline & SC2 & 0.796 & & \\
\hline & SC3 & 0.720 & & \\
\hline & SC4 & 0.802 & & \\
\hline & SC5 & 0.813 & & \\
\hline
\end{tabular}


Table 2: Discriminant Validity using Fornell and Larcker Criterion

\begin{tabular}{|l|l|l|l|l|l|l|}
\hline & COM & MC & RULE & SC & SKNOW & TRAIN \\
\hline COM & $\mathbf{0 . 9 0 2}$ & & & & & \\
\hline MC & 0.718 & $\mathbf{0 . 7 8 2}$ & & & & \\
\hline RULE & 0.307 & 0.336 & $\mathbf{0 . 7 8 4}$ & & & \\
\hline SC & 0.434 & 0.401 & 0.457 & $\mathbf{0 . 7 8 3}$ & & \\
\hline SKNOW & 0.352 & 0.432 & 0.458 & 0.532 & $\mathbf{0 . 7 8 7}$ & \\
\hline TRAIN & 0.451 & 0.452 & 0.277 & 0.465 & 0.408 & $\mathbf{0 . 8 1 4}$ \\
\hline
\end{tabular}

The other method of assessing discriminat validity is by using Heterotrait-Monotrait Ratio (HTMT) technique developed by Henseler et al., (2014) but instead to three problems with Ro lu00a8nkko lu00a8 and Evermannlu2019s study: (a. As shown in Table 3, all the values fullfill the criterion of HTMT.90 (Gold, Malhotra, \& Segars, 2001) and the HTMT.85 (Kline, 2015). This indicates that discriminant validity has been ascertained. Besides, the result of HTMT inference also shows that the confidence interval does not show a value of 1 on any of the constructs (Henseler et al., 2014) but instead to three problems with Ro lu00a8nkko lu00a8 and Evermannlu2019s study: (a, which also confirms discriminant validity.

Table 3: HTMT Criterion

\begin{tabular}{|l|l|l|l|l|l|l|}
\hline & COM & MC & RULE & SC & SKNOW & TRAIN \\
\hline COM & & & & & & \\
\hline MC & 0.797 & & & & & \\
\hline RULE & 0.341 & 0.374 & & & & \\
\hline SC & 0.489 & 0.456 & 0.517 & & & \\
\hline SKNOW & 0.389 & 0.480 & 0.521 & 0.609 & & \\
\hline TRAIN & 0.494 & 0.508 & 0.305 & 0.530 & 0.463 & \\
\hline
\end{tabular}



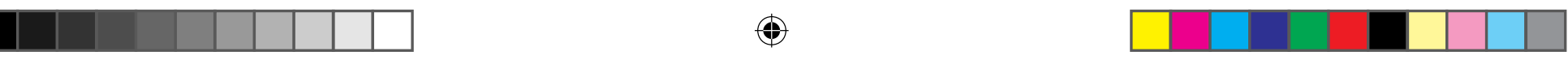

\subsection{Assessment of Structural Model}

After assessing the measurement model, the structural model was assessed using SPSS 20 and SmartPLS 2.0. To assess the structural model, collinearity, path coefficients, coefficient of determination, effect size, and predictive relevance were examined. In tandem with the usage of SEM, independent variables are called exogenous variables while dependent variables are called endogenous variables.

\subsubsection{Collinearity Assessment}

First of all, the variance inflation factor (VIF) values for all exogenous variables were examined to assess collinearity. Using SPSS 20, competitive psychological climate and affective commitment were regressed against turnover intention to obtain the VIF values. The VIF values are 1.032 for both competitive psychological climate and affective commitment. None of the variables have a VIF value above 5.00, which is the recommended cut-off value (Hair et al., 2014). Therefore, there is no collinearity issue in this study.

\subsubsection{Hypothesis Testing}

Bootstrapping was performed in SmartPLS 3.0 to obtain the standardised path coefficients, standard errors, and $t$ values in order to assess the significance of each hypothesised relationship. Figure 2 illustrates the results of the path analysis. From Table 4 below, it was found that safety communication has a significant positive relationship with safety culture $(\beta=0.189, p<0.01)$. Same goes to the relationship between safety rule $(\beta=0.216, p<$ $0.01)$, safety knowledge $(\beta=0.289, p<0.01)$ and safety training $(\beta=0.212, p<0.01)$ towards safety culture with positive significant relationship. Thus, all hypothesis $\mathrm{H} 1, \mathrm{H} 3$, $\mathrm{H} 4$ and $\mathrm{H} 5$ are supported. Apart from these relationships, a negative relationship is found between management commitments towards safety culture $(\beta=-0.027, p>0.01)$. Thus hypothesis $\mathrm{H} 2$, is rejected.

The coefficients of determination (R2) for safety culture in this research is 0.424 . It can be interpreted that all the investigated factors explain $42.4 \%$ of variance in safety culture. It means that $57.6 \%$ of the variance in safety culture is explained by other factors which are not covered in this study. 
Table 4: Summary of Hypothesis Testing

\begin{tabular}{|l|c|c|c|l|l|}
\hline \multicolumn{1}{|c|}{ Hypothesis } & Relationship & $\begin{array}{c}\text { Path } \\
\text { Coefficient (b) }\end{array}$ & Standard error & t-value & Decision \\
\hline COM $\rightarrow$ SC & $\mathrm{H} 1$ & 0.189 & 0.058 & $3.261^{* * *}$ & Supported $^{* *}$ \\
\hline $\mathrm{MC} \rightarrow \mathrm{SC}$ & $\mathrm{H} 2$ & -0.027 & 0.068 & 0.398 & Not Supported \\
\hline $\mathrm{RULE} \rightarrow \mathrm{SC}$ & $\mathrm{H} 3$ & 0.216 & 0.046 & $4.708^{* \star *}$ & Supported \\
\hline SKNOW $\rightarrow$ SC & $\mathrm{H} 4$ & 0.289 & 0.050 & $5.797^{* * *}$ & Supported ${ }^{* *}$ \\
\hline TRAIN $\rightarrow$ SC & $\mathrm{H} 5$ & 0.212 & 0.050 & $4.289^{* * *}$ & Supported \\
\hline
\end{tabular}




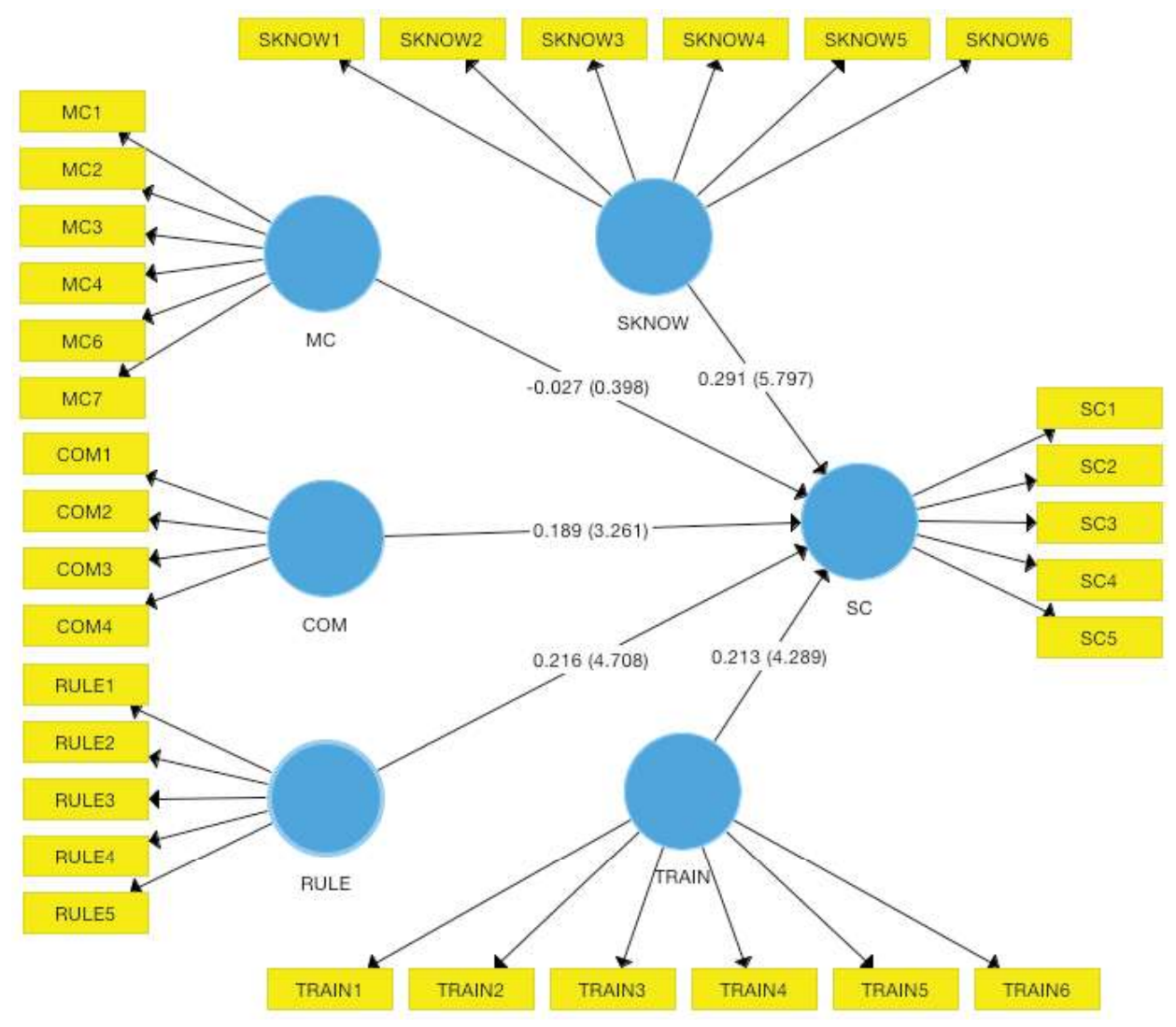

Figure 2: Result of Path Analysis

\subsubsection{Effect Size}

Apart from looking at the R2 alone, the change in R2 value when a specific exogenous variable is omitted from the model was also examined in order to assess the magnitude of the impact of that particular exogenous variable on an endogenous variable (Hair et al., 2014). Effect size serves as a practical guide to interpret the practical importance of a specific relationship (Preacher \& Kelley, 2011). This can be done by examining the f2 effect size for each relationship and the results are shown in Table 4 below. The f2 effect size is calculated manually (Hair et al., 2014) and the formula is shown below as a note directly below Table 4. 


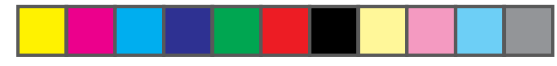

Table 5: Effect Size for Direct Effect

\begin{tabular}{|l|c|c|}
\hline Relationship & $\boldsymbol{f}^{2}$ Effect Size & Magnitude \\
\hline $\mathrm{COM} \odot \mathrm{SC}$ & 0.029 & Small \\
\hline $\mathrm{RULE} \rightarrow \mathrm{SC}$ & 0.061 & Small \\
\hline SKNOW $\rightarrow$ SC & 0.099 & Small \\
\hline TRAIN $\rightarrow$ SC & 0.056 & Small \\
\hline
\end{tabular}

According to Cohen (1988), the rule of thumb is that the f2 values of $0.02,0.15$, and 0.35 represent small, medium, and large effect size respectively. Based on the rule of thumb, it can be interpreted that safety communication has a small effect on safety culture amounting to $2.9 \%$. The same results on the effect size of safety rule, safety knowledge and safety training towards safety culture with the amounting of $6.1 \%, 9.9 \%$ and $5.6 \%$. However, a small effect size does not necessarily imply the effect is not important (Chin, Marcolin, \& Newsted, 2003; Preacher \& Kelley, 2011). Furthermore, since all of these four hypothesised relationships were already shown to be statistically significant, all of the relationships here are deemed important and meaningful judging by the effect sizes found.

\subsubsection{Predictive Capability of the Model}

The predictive capability of the model can be assessed by calculating the predictive relevance (Q2), which measures the predictive relevance of the model. Hair et al. (2014) recommended the cross-validated redundancy to calculate Q2. According to the rule of thumb, Q2 greater than 0 (zero) indicates that the exogenous variables have predictive relevance on the particular endogenous variable, whereas Q2 less than zero indicate that there is no predictive relevance (Hair et al., 2014). The Q2 was calculated by using a blindfolding procedure in SmartPLS 3.0. Blindfolding is a sample reuse techniques that omits every dth data point in the construct's indicators of the endogenous variable and uses the resulting estimates to predict the omitted part (Hair et al., 2014). An omission distance between 5 and 10 is recommended to be used to calculate the Q2 (Hair et al., 2014). In this study, an omission distance of 7 was chosen to calculate the Q2. Blindfolding procedure was calculated for the endogenous variable and the Q2 value is 0.239 for safety culture. The Q2 value for the endogenous variables is above zero and therefore, it indicates that the model has predictive relevance. 


\subsection{Recommendation}

Although there are many issues arise regarding the education sector's poor safety and fatal accidents occurred during working at their workplace, there are few ways that the top mangement, the government or even the respective ministries can practise in order to improve the teachers' safety at school in Malaysia. In order to improve the instructor's/teachers' safety in the school, a qualified health officer should be made necessary to be allocated in every school registered under the Companies Act 1965. A competent safety and health officer has to be appointed which have been gazetted by the Minister and the safety and health officer's job is to ensure compliance with the Occupational Safety and Health Act which came into force in February 1994 and promote safe conduct of work. Safety precautions can be improved with the briefing and disciplinary actions reinforced by the safety and health officers to all the instructor/teachers in the school. Through these actions, the instructors/ teachers will understand more about safety precautions in workplace and eventually, fatal accidents by the instructors/ teachers can also be reduced.

\subsection{Discussion and Conclusion}

This research provided us some knowledge and insight on safe work culture and we have studied the factors that influence the effectiveness of safe work culture in education sector. The results that have been obtained in this study will be beneficial in terms of correcting and improving the current implementation in the vocational college as one of the organization providing technical knowledge to the students, so that the best action can be taken to improve safety and health in the vocational college and also other organization in education sector. People knew that, safety culture is not just a day of implementation; it is an on-going process of safety behaviour to the work environment. In conclusion to create a positive safety culture, Government especially Ministry of Education (MOE) needs to enforce the compliance of Occupational Safety and Health Act 1994 to make sure that all organisations in education sector will follow the guidelines of safe work culture. Government also needs to carry out some campaigns, workshops and trainings to increase instructors/teachers awareness of safe work culture and the necessary to follow the rules and regulations. Both the management and instructors/teachers need to play their own roles and responsibility in order to ensure the objective of safety culture is achieved. 


\section{References}

Abdullah, N. A. C. (2010). Occupational Health and Safety Management Perceptions in Malaysian Public Hospitals : Implications for the Implementation of Standardized Management Systems. Phd Thesis. Curtin University of Technology.

Choudhry, R. M., Fang, D., \& Mohamed, S. (2007). The nature of safety culture: A survey of the state-ofthe-art. Safety Science, 45(10), 993-1012. http://doi.org/10.1016/j.ssci.2006.09.003

Cohen, A., \& J.Colligan, M. (1998). Assessing Occupational Safety and Health Training. Ohio.

Cooper, D. (2002). Safety Culture: A Model for understanding \& quantifying a difficult concept.

Cram, R. S. (2015). A Paradigm Shift In Organisational Safety Culture Evaluation And Training. Lancaster University,UK.

DOSH. (2017). Statistik Kemalangan Pekerjaan Mengikut Sektor Sehingga Oktober 2017. Retrieved from http://www.dosh.gov.my/index.php/ms/in-the-news/489 statistik/occupationalaccidentsstatistics/1666-occupational-accidents-statistics-by-state until-october-2017

Feng, X. Q., Acord, L., Cheng, Y. J., Zeng, J. H., \& Song, J. P. (2011). The relationship between management safety commitment and patient safety culture. International Nursing Review, 58(2), 249-254. http://doi.org/10.1111/j.1466-7657.2011.00891.x

Guldenmuld, F. (2010). Understanding and Exploring Safety Culture. http://doi.org/10.1111/j.15396924.2010.01452.x

Hair, Hult, Ringle, \& Sarstedt, (2014). A Primer on Partial Least Squares Structural Equation Modeling (PLS-SEM). Long Range Planning (Vol. 46). http://doi.org/10.1016/j.Irp.2013.01.002

Hale, A. R. (2000). Culture's confusions. Safety Science, 34, 1-14. http://doi.org/16/S0925-7535(00)000035

Henseler, J., Dijkstra, T. K., Sarstedt, M., Ringle, C. M., Diamantopoulos, A., Straub, D. W., Calantone, R. J. (2014). Common beliefs and reality about PLS: Comments on Ronkko and Evermann (2013). Organizational Research Methods, 17(2), 182-209. http://doi.org/10.1177/1094428114526928

Henseler, J., Ringle, C. M., \& Sarstedt, M. (2014). A new criterion for assessing discriminant validity in variance-based structural equation modeling. Journal of the Academy of Marketing Science, 43(1), 115-135. http://doi.org/10.1007/s11747-014-0403-8

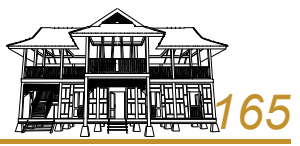




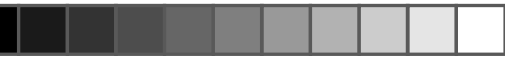

Ho, J. K. L., \& Zeta, K. C. (2004). Cultural factors and their Significance to the Hong Kong construction industry, 238-245.

Ibrahim, M. E., Hallaq, K. A. M. Al, \& Enshassi, A. A. (2012). Safety climate in construction industry the case of gaza strip. The 4th International Engineering Conference -Towards Engineering of 21st Century, 1-14.

Idrus, D., Rahman, H. A., Ashari, H., Zaini, F., Jamil, R., \& Muktar, S. N. (2004). Level Of Awareness Of UTM Staff On Occupational Safety And Health At The Workplace. Johor, Malaysia.

Ismail, F., Ahmad, N., Janipha, N. A. I., \& Ismail, R. (2012). The Behavioural Factors' Characteristics of Safety Culture. Journal of Asian Behavioural Studies, 2, 67-75. Retrieved from http://fspu.uitm. edu.my/cebs/images/stories/cebs/jabsv2n4jan2012c7.pdf

Ismail, F., Salimin, R. H., \& Ismail, R. (2012). The Organisational Environment-Behaviour Factor's Towards Safety Culture Development. Procedia - Social and Behavioral Sciences, 35(December 2011), 611-618. http://doi.org/10.1016/j.sbspro.2012.02.128

Kline, R. B. (2015). Principles and Practice of Structural Equation Modeling. (T. D. Little, Ed.) (Third Edit, Vol. 1). New York, London: The Guilford Press. http://doi.org/10.1017/CBO9781107415324.004

Kock, N. (2015). Common method bias in PLS-SEM: A full collinearity assessment approach. International Journal of E-Collaboration, 11(4), 1-10. http://doi.org/10.4018/ijec.2015100101

Koo, K. E., Nurulazam, M. . A., Rohaida, M. . S., Teo, T. G., \& Salleh, Z. (2014). Examining the Potential of Safety Knowledge as Extension Construct for Theory of Planned Behaviour: Explaining Safety Practices of Young Adults at Engineering Laboratories and Workshops. Procedia - Social and Behavioral Sciences, 116(0), 1513-1518. http://doi.org/http://dx.doi.org/10.1016/j.sbspro.2014.01.426

Kumar, R., Chelliah, T. D., Chelliah, M. K., \& Amin, F. M. (2012). An analysis on safety work culture in Malaysian manufacturing industry. BIOINFO Business Management, 2(1), 11-15.

Makhtar, N. K., Parasuraman, B., Zakaria, M. N., \& Ismail, A. R. (2018). Safety Culture and Its Contributing Factor in Education Sector in Malaysia. In P. Arezes (Ed.), Advances in Safety Management and Human Factors: Proceedings of the AHFE 2017 International Conference on Safety Management and Human Factors, July 17--21, 2017, The Westin Bonaventure Hotel, Los Angeles, California, USA (pp. 456-464). Cham: Springer International Publishing. http://doi.org/10.1007/978-3-31960525-8_47 
Öner, S., Tanır, F., Aktaş, H., Okyay, R. A., \& Şaşmaz, T. (2017). Use Of Personal Protective Equipment And Factors Associated With Injuries Among Vocational Technical High School Students. Nobel Medicus, 13(2), 28-35.

Podsakoff, P. M., MacKenzie, S. B., Lee, J. Y., \& Podsakoff, N. P. (2003). Common method biases in behavioral research: a critical review of the literature and recommended remedies. Journal of Applied Psychology, 88(5), 879-903. http://doi.org/10.1037/0021-9010.88.5.879

Reinhold, K., Siirak, V., \& Tint, P. (2014). The Development of Higher Education in Occupational Health and Safety in Estonia and Selected EU Countries. Procedia - Social and Behavioral Sciences, 143, 52-56. http://doi.org/10.1016/j.sbspro.2014.07.356

Ringle, C. M., Wende, S., \& Becker, J.-M. (2015). SmartPLS 3. Hamburg: SmartPLS. Retrieved from http://www.smartpls.com

Roldán, J. L., Felipe, C., \& Leal-Rodríguez, A. (2015). Information systems capabilities and organizational agility : Understanding the mediating role of absorptive capacity when influenced by a hierarchy culture. 2nd International Symposium on Partial Least Squares Path Modeling, 1-12. http://doi. org/10.3990/2.332

Shea, T., De Cieri, H., Donohue, R., Cooper, B., \& Sheehan, C. (2016). Leading indicators of occupational health and safety: An employee and workplace level validation study. Safety Science, 85, 293304.

Skeepers, N. C., \& Mbohwa, C. (2015). A Study on the Leadership Behaviour, Safety Leadership and Safety Performance in the Construction Industry in South Africa. Procedia Manufacturing, 4, 1016. http://doi.org/10.1016/j.promfg.2015.11.008

Sukadarin, E. H., Suhaimi, N. S., \& Abdull, N. (2012). Preliminary Study of the Safety Culture in a Manufacturing Industry. Internatonal Journal of Humanities and Social Science, 2(4), 176-183.

Usman, I., \& Rashid, A. M. (2014). Safety Awareness Among Pre-Service Teachers of Technical and Vocational Education in Malaysia. Middle-East Journal of Scientific Research, 22(5), 655-660. http:// doi.org/10.5829/idosi.mejsr.2014.22.05.21947

Vecchio-sadus, A. M. (2007). Enhancing Safety Culture Through Effective Communication, 1-9.

Vinodkumar, M. N., \& Bhasi, M. (2010). Safety management practices and safety behaviour: Assessing the mediating role of safety knowledge and motivation. Accident Analysis and Prevention, 42(6), 2082-2093. http://doi.org/10.1016/j.aap.2010.06.021 
Vinzi, V. E., Chin, W. W., Henseler, J., \& Wang, H. (2010). Handbook of Partial Least Squares: Concepts, Methods and Applications. (J. E. Gentle, W. K. Hardle, \& Y. Mori, Eds.). Springer. http://doi. org/10.1007/978-3-642-16345-6

Zohar, D. (1980). Safety Climate in Industrial Organizations: Theoretical and Applied Implications. The Journal of Applied Psychology, 65(1), 96-102. http://doi.org/10.1037/0021-9010.65.1.96 